CURRENT RESEARCH JOURNAL OF PHILOLOGICAL SCIENCES 2(5): 33-38,

May 2021 DOI: https://doi.org/10.37547/philological-crjps-02-05-10

ISSN 2767-3758

(C)2021 Master Journals

Crossref doi) 8 Google

Accepted25 $5^{\text {th }}$ May, 2021 \& Published 31 ${ }^{\text {th }}$ May, 2021

\title{
PRAGMATIC PROPERTIES OF APPLICATION FORMS OF UZBEK LANGUAGE FORMS
}

\author{
Dildora Dilmuradovna Pulatova
}

Independent Applicant (Phd), Teacher Of The Uzbek Language And Literature Department, Shakhrisabz Branch Of The Tashkent State Pedagogical University Named After Nizami

\section{ABSTRACT}

As with any language unit, the pragmatic aspect of the application forms has its own characteristics. Such units, which represent different meanings, add additional meanings to the main proposition in the communication process. Because the state of speech, or rather the relationship between the speaker and the listener, is the basis of pragmatic research. The pragmatic aspect is one of the new directions in Uzbek linguistics, It is important to study in a new aspect, ie pragmatically, the forms of communication used in the process of interpersonal communication in the Uzbek language. In Uzbek linguistics, the units of reference are interpreted in the form of stimuli, and in the researches of some linguists, they are interpreted as forms of appeals, and in the researches the forms of appeals are studied in detail. This article discusses the use of appeal units in the communication process, the pragmatic features of appeal forms, including dysphemisms, the deictic functions of appeal forms, the presuppositional features, and the role and importance of nonverbal means in address expression.

KEYWORDS:- Sociolinguistics, pragmatics, forms of address, speech culture, culture of communication, communication behavior, speech situation, addressee, addressee, deictic functions of address forms, presuppositional features, verbal means, nonverbal means, dysphemisms, units of communication, communication

\section{INTRODUCTION}

Since the use of language units is often associated with non-linguistic sociopsychological aspects, unlike social linguistics (social linguistics), which studies language as a social phenomenon, linguistic units are required to live in speech. A new branch of linguistics, sociolinguistics, has been formed. [1:481,482].

Therefore, in society, forms of communication have a special place in the process of human interaction. A culture of communication is an essential element of any national culture. Communication behavior, stable communication formulas, rich national experience, uniqueness of customs, way of life, living conditions of each nation are reflected in its language. Therefore, in society, forms of communication have a special place in the process of human interaction. A culture of communication is an essential element of any national culture. Communication behavior, stable communication formulas, rich national experience, uniqueness of customs, way of life, living conditions of each nation are reflected in its language.

After the 1950s, a pragmatic approach to linguistics became widespread. [2:389-390]. A new aspect of the study of forms of communication in the Uzbek language, ie pragmatic or sociopragmatic research, not only reveals the linguistic features of speech, but also 
CURRENT RESEARCH JOURNAL OF PHILOLOGICAL SCIENCES 2(5): 33-38,

May 2021 DOI: https://doi.org/10.37547/philological-crjps-02-05-10

ISSN 2767-3758

(C)2021 Master Journals

\section{Crossref do) 81 Google}

Accepted25 $5^{\text {th }}$ May, 2021 \& Published 31 ${ }^{\text {th }}$ May, 2021

the social function of forms of speech in speech, their differentiation, forms of speech in speech. It allows for comprehensive coverage of many aspects of speech, such as its connection with national thinking and nationalism, and its relation to culture.

In Uzbek linguistics, the units of reference are interpreted in the form of stimuli, and in the research of some linguists, they are interpreted as forms of appeal. The study examined the application forms in detail. In this article, we will focus on the pragmatic features of application forms. Reference units are an important part of communication. Because the right or wrong choice of forms of communication in the process of communication, even the tone can lead to a positive or negative outcome of the communication.

\section{Methods}

It can be said that the starting point (period) of the development of the language system begins with pragmatics [3:40]. Language is an important tool in the expression of human thoughts and goals in society. In the process of communication, the goals of the speaker (addressee) and the listener (addressee) combine to form a purposeful communication. The relationship between the addressee and the addressee is age, gender, kinship, social position (big, equal, small), social status (young, friend, acquaintance, stranger), communication environment (formal, informal), distance (long, close), the purpose of communication (to attract attention, to express attitude to the interlocutor, to ask, to apologize, etc.), the tone of communication (formal, sincere, sarcastic, sarcasm, begging, begging) level of knowledge has a major impact on how communication ends [4:7].

As with any language unit, the pragmatic aspect of the application forms has its own characteristics. Such units, which represent different meanings, add additional meanings to the main proposition in the communication process. Because the state of speech, or rather the relationship between the speaker and the listener, is the basis of pragmatic research. The communicator not only conveys the information to himself, but also expresses his personal attitude to it and aims to fully convey his purpose to the listener. This understanding gives the listener a certain attitude to the message and is not limited to the acquisition of information. A pragmatic study of such units in any language, including Uzbek, is important because of the clear understanding of emotions, moods, desires, and other meanings in the communication process.

Pragmatics is a separate branch of linguistics in which the study of the selection and use of linguistic units in the process of communication and the impact of these units on the participants of communication are studied. These rules are explored in a broader context than the context of communication [3:76].

Pragmatics expresses the speaker's attitude to the material being, the content of the message, the addressee (listener), the tone of speech in the presence of the speaker and the listener in the communicative act (confidence, determination, courage, fear, insecurity, suspicion, suspicion, joy, etc.), the use of lexical units, the use of nonverbal means, and communicative elements are considered important and provide additional information about communicants. [5: 77,79]

The pragmatic function of language units arises in relation to context, speech situation, language skills of speakers, and general knowledge of the object of speech [6: 74,76].

Factors such as speech, the content being spoken, the situation, the spiritual, spiritual, and mental closeness of the speaker and the listener also help to clarify the pragmatic content in oral communication [7: 27,29]. When studying the 
CURRENT RESEARCH JOURNAL OF PHILOLOGICAL SCIENCES 2(5): 33-38,

May 2021 DOI: https://doi.org/10.37547/philological-crjps-02-05-10

ISSN 2767-3758

(C)2021 Master Journals

\section{Crossref do) 81 Google}

Accepted25 $5^{\text {th }}$ May, 2021 \& Published 31 ${ }^{\text {th }}$ May, 2021

pragmatic features of the forms of appeal, the deictic functions of the forms of direct appeal, the presuppositional features, the role of nonverbal means in the expression of forms of appeal should be highlighted. With this in mind, we have tried to analyze these features of the application forms.

\section{Deictic functions of reference forms}

The use of deictic units is observed as early as the ontogenetic period of speech formation. During this period, the child regularly learns the deictic units that are actively used in everyday life. This has a positive effect on the development of the child's socialization process [8:17].

Often, when the term kinship is used as a unit of reference in the speech of young children, these units of appeal are given a deictic function.

From the age of 8-9 months, the child learns lexical units that are easy to pronounce. Some children aged 10-11 months may also assign two or more deictic tasks to a particular unit [8:18]. For example, children in different regions speak differently in terms of dialect, and in their speech, they use the word dad, daddy, to refer not only to their father but also to their mother, grandfather, grandmother and other family members.

Dysphemisms used as nicknames in children's speech also play a deictic role. Dysphemisms, which form a metaphorical personality dexterity based on outward resemblance, are common in the speech of school-age children [8:18].

Dysphemism is the naming of an animal or thing that is considered negative in nature in order to insult and discriminate, rather than naming people by their own names. Examples of dysphemism include pig, fox, snake, scorpion, donkey, cattle, and ox. The use of dysphemism in communication means that the speaker treats the listener with ridicule, mockery, and disrespect. For example, it is used as a nickname in the speech of school-age children. A stork for a tall child, a turtle for a slow-moving child, and so on. There are many ways to use words and call them with these words: Hey, Stork, where are you going? (At school, children call Sarvar "Stork"). (Muxsinov Diyorbek, 14 years old). In addition, in public discourse, it is possible to observe the use of these desphemisms as a unit of reference by adults in situations of reprimanding young children, young children. This necessitates the need to increase the speech culture of the people in the society. Because the use of these dysphemisms as a unit of reference has a negative impact on the psychology of the child.

\section{Presuppositional features of appeal forms}

Presupposition is another phenomenon that determines the content of a text and speech structures in general. Hundreds of years ago, the German logician $H$. Frege stated that presupposition is related to secret judgment [3: 123].

For proper and real communication, communicators must be familiar with certain facts prior to the speech situation, and have certain knowledge about the general situation. It is these facts that knowledge is generalized in linguistics under the name of pressuposition [9:29].

Pressure greatly influences the communication process. For example, a person who wants to say something to someone, first of all, takes into account the fact that the addressee is connected with the press position of the speech he wants to say. That is, for an addressee who is already familiar with the reality of what is being said, it is sufficient for the addressee to state the main idea in one or more words. For example, for a mother who is anxiously waiting for her son, who is late for an unknown reason, the word "came" from the person who left to visit him is the same as the word "came" from his son (not someone else). 
CURRENT RESEARCH JOURNAL OF PHILOLOGICAL SCIENCES 2(5): 33-38,

May 2021 DOI: https://doi.org/10.37547/philological-crjps-02-05-10

ISSN 2767-3758

(C)2021 Master Journals

\section{Crossref do) 81 Google}

Accepted25 $5^{\text {th }}$ May, 2021 \& Published 31 $1^{\text {th }}$ May, 2021

gives the message that it came from the waiting place [10:16]. There are many examples of this. To a mother who is waiting for the start of a wellwatched TV series in the evening, her son's words "The moon has begun" indicate that it is time to give this series, the beginning of the waiting series (not another series); Dada bought Nasiba's brother Lacetti. To tell this message, the speaker must know that there is a girl named Nasiba. The speaker may also know that Nasiba has only one brother and that he is paid enough to buy a car. The presupposer who provides this information is the speaker.

During the speech, the press also expresses a specific communicative content.

\section{Representation of forms of appeal by nonverbal means}

As you know, a conversation between two people is a dialogue. In fact, any speech process takes place in two different ways. The first is through linguistic means in the language: through words and phrases, and the second is through nonverbal means, which have their own content and function in each language. These tools can be used separately or in parallel. Such linguistic and non-linguistic means are used in the process of communication, depending on the state of communication, the interaction of communicators, the topic of conversation, the nature and situation of communication.

Compared to written speech, oral communication conveys information to the addressee quickly and clearly, simply and concisely. Sometimes in dialogic texts the word, the sentence, and sometimes the whole text can be elliptical (abbreviated) or replaced by a nonverbal means that can replace these linguistic means [11:70]

The dialogic texts often given in the fiction, as well as the discourse analysis in oral speech, show that the non-linguistic means used by the participants in the process of verbal communication, i.e. head movements, body movements, hand movements, co. $\mathrm{z}$ actions, nonverbal means such as default are used for purposes such as interpretation, addition, emphasis, clarification, approval, rejection, and represent these additional meaning ottenkas. The communicative content of non-verbal means used in communication is almost indistinguishable from the content understood through verbal forms of communication, but we can say that the content expressed through nonverbal means is emotionally brighter and more effective than verbal means. In some cases, the nonverbal medium is selected first, followed by the linguistic means appropriate to the nonverbal medium. For example:

When the children saw their teacher coming from the road, they went to the side of the road and put their hands on their chests:

\section{- "Good morning, teacher!"}

It should be noted that the expression of the appeal in the process of communication is significantly different from such forms as affirmation, denial, emphasis. For example, both a linguistic tool and a non-linguistic tool can be used to express affirmation or denial in an appeal process. That is, the meaning of affirmation or denial can be expressed, of course, with the words bopti, or with a single nod. However, it is rare for an appeal to be expressed using such a single nonverbal tool. Sometimes a single nonverbal means may be enough to express an appeal. For example, when addressing a child who is far away, it can be expressed by gestures such as "Son, come here." But in most cases, linguistic and non-linguistic means are involved together to express the appeal.

According to the results of the analysis of human interaction processes in social society or dialogic texts in the literature, it can be said that first a non-verbal means can be used: nod, then nod, 
CURRENT RESEARCH JOURNAL OF PHILOLOGICAL SCIENCES 2(5): 33-38,

May 2021 DOI: https://doi.org/10.37547/philological-crjps-02-05-10

ISSN 2767-3758

(C)2021 Master Journals

\section{Crossref do) 81 Google}

Accepted25 $5^{\text {th }}$ May, 2021 \& Published 31 ${ }^{\text {th }}$ May, 2021

and then linguistic means can be used to interpret and supplement it. Sometimes a call can only be made through a nonverbal means. For example,

Because the students at the event were a bit noisy, the teacher did not say to them, "Students, shut up!" The teacher closed his mouth and put his index finger on his lips. laid horizontally, this "students, be quiet!" loaded the function that the word performs into a single signal. The students understood the teacher's gesture and the noise stopped.

\section{Results AND DISCUSSIONS}

As language develops in tandem with the development of society, human thought, and emotion, the lexical meaning of the word, the semantic structure, expands. Subjective relationships play an important role in the development of such a meaning of the word. At the same time, "social life, the material world, differences in a particular environment, peculiarities create imbalances in the system of concepts" [12:89].

Even in the unusual units of speech found in children's speech, there is an expression of connotation and evaluation that is not observed in adults: "Good morning, good uncle!" He said.

In the process of addressing, linguistic and nonlinguistic means complement, interpret and emphasize each other. The use of gestures and facial expressions helps to narrow down the speech and fill it with meaning. The combination of these tools can sometimes be used to reinforce and emphasize meaning.

The main task of the appeal - to attract attention, to invite the interlocutor. As the appeal is studied from different angles, their functions are also presented differently. The forms of communication define the social relations of the interlocutors on the basis of their socially regulating functions. Forms of communication, according to their methodological tasks, represent the tone of communication, the functional area of communication. In some scientific literatures, words that contain utterances are called "vocative words" [13:12].

\section{Conclusion}

Forms of communication are of great importance for the necessary conduct of communication in all nations. The application can specify the social group to which the addressee belongs, his age, gender, and position. The units of speech are the units of speech that reflect the values, customs, national identity, as well as the subtleties of the culture of speech of that people. They are effective means of expressing the subjective attitude of the speaker towards the listener through various means, such as caress, joy, respect, satisfaction, anger, hatred, discrimination. The means of communication are directly related to the worldview, level of spirituality, morality, taste, intelligence, religious worldview of language speakers, in particular, their attitude to reality, their speech culture. In Uzbek linguistics, the study of linguistic units, including forms of address, from a pragmatic point of view is of great importance. At the heart of pragmatic research is the state of speech, especially the relationship between speaker and listener. Hence, the pragmatic features of appeal forms are expressed by deictic functions, presuppositional features, linguistic and nonlinguistic means of address forms.

\section{ReFERENCES}

1. Linguistic Encyclopedic Dictionary. Chief editor V.N. Yartseva. - M.: Sov. Encyclopedia, 1990.

2. Philosophical Encyclopedia. Vocabulary. - 
CURRENT RESEARCH JOURNAL OF PHILOLOGICAL SCIENCES 2(5): 33-38,

May 2021 DOI: https://doi.org/10.37547/philological-crjps-02-05-10

ISSN 2767-3758

(C)2021 Master Journals

Crossief do) 88 Google

Accepted25 $5^{\text {th }}$ May, 2021 \& Published 31 ${ }^{\text {th }}$ May, 2021

M., 1983. -- S. 147, 389-390.

3. Safarov Sh Pragmalinguistics. Tashkent 2008. B-76

4. Balakay AA Etiquette addresses: functional-semantic and lexicographic aspects: abstract of thesis. diss. ... Cand. philol. Sciences / A. A. Balakay. Novokuznetsk, 2005.

5. Saidkhonov M. Literary text as a communicative tool // Uzbek language and literature, 2009, issue 5, pages 77-79.

6. Lutfullayeva D., Jumayev F. Pragmatic features of Uzbek verbs // Uzbek language and literature, 2008, issue 2, pages 74-76.

7. Karimova F. The role of pragmatics in dialogues // Language and literature education. 2006, № 3, pp. 27-29.

8. Kurbanova M. Pragmatic features of Uzbek children's speech. Ph.D. Auto abstract of dissertation. Tashkent, 2018. P-17.

9. Mahmudov N. Press position and speech // Uzbek language and literature, 1985, issue 6 , page 29.

10. Muminov S. Socio-linguistic features of Uzbek communication behavior. Doctor of Philological Sciences. Thesis auto abstract. T. 2000. p.16.

11. Saidkhonov M. Communicative analysis of dialogic speech // Uzbek language and literature, 2004, issue 4, page 70

12. Safarov Sh. Semantics. Tashkent, 2013. B89

13. Urinboyev B. Vocabulary category in modern Uzbek language. Tashkent, 1972., bet-12

14. Bozorova M.M. Linguistic features of speech units in Uzbek language expressing positive content. Dissertation of the candidate of philological sciences
Tashkent, 200717 p

15. Akbarova Z. Application forms in the Uzbek language and its linguistic research. Dissertation of the candidate of philological sciences Tashkent, 2007 